\title{
Measurement of formic acid, acetic acid and hydroxyacetaldehyde, hydrogen peroxide, and methyl peroxide in air by chemical ionization mass spectrometry: airborne method development
}

Victoria Treadaway et al.

Correspondence to: Victoria Treadaway (vtreada@uri.edu)

The copyright of individual parts of the supplement might differ from the CC BY 4.0 License. 
Table S1: Literature summary for glycolaldehyde surface and aircraft measurements based on source type

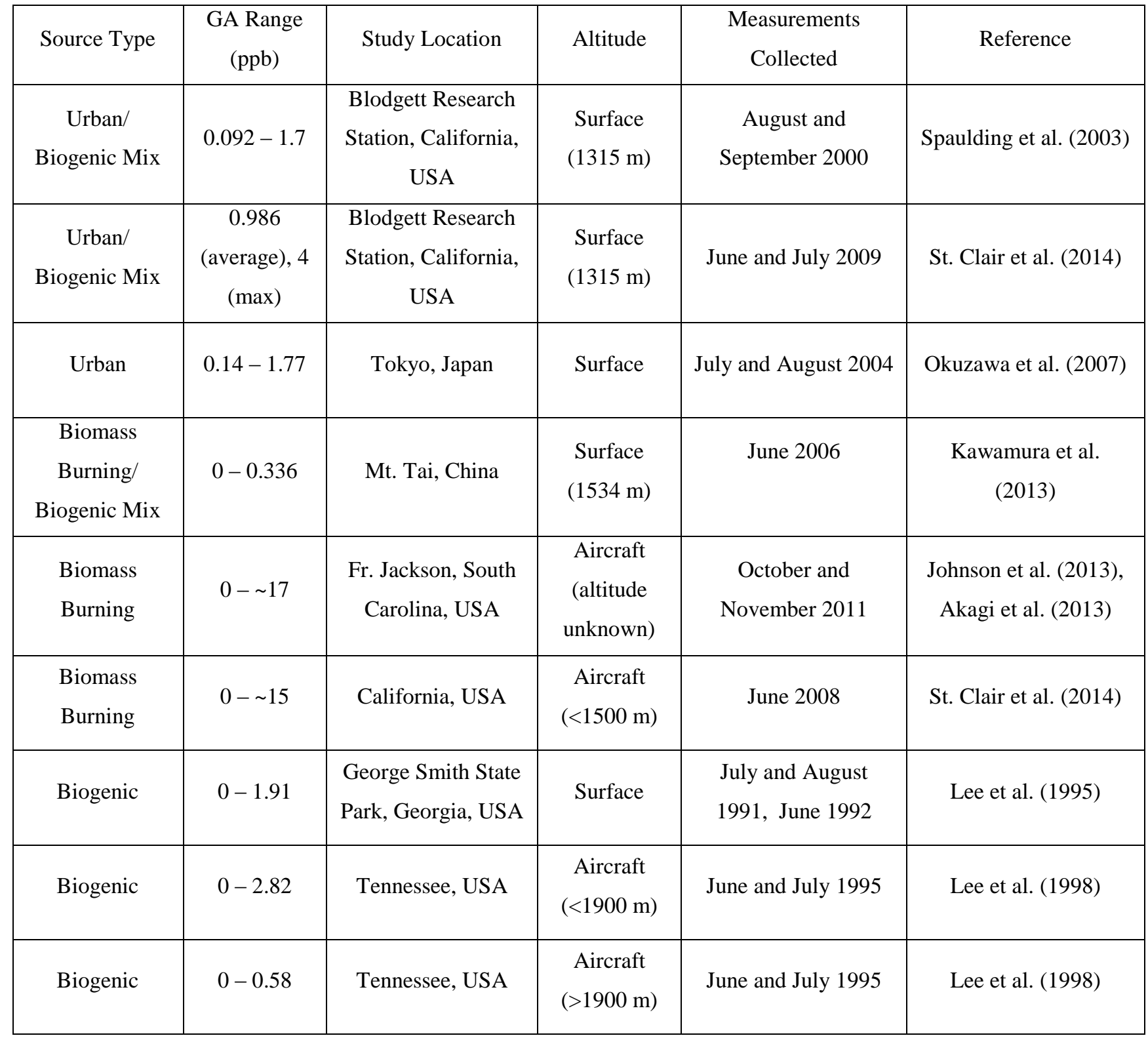


Table S2: Reaction cell mixing ratios for glycolaldehyde based on Betterton and Hoffmann (1988) and Kua et al. (2010) in parts per billion (ppb) for the three experimental cases at the five tested equilibration air flow rates

\begin{tabular}{|c|c|c|c|}
\hline \multirow{2}{*}{$\begin{array}{c}\text { Aadco flowrate } \\
(\mathrm{sccm})\end{array}$} & \multicolumn{3}{|c|}{ Glycolaldehyde Reaction Cell Mixing } \\
& Ratio (ppb) \\
\cline { 2 - 4 } & Case 1 & Case 2 & Case 3 \\
\hline 100 & 3.3 & 3.2 & 0.20 \\
\hline 200 & 6.5 & 6.3 & 0.39 \\
\hline 300 & 9.6 & 9.3 & 0.58 \\
\hline 400 & 13 & 13 & 0.76 \\
\hline 500 & 16 & 15 & 0.94 \\
\hline
\end{tabular}


Table S3:The expected GA reaction cell mixing ratio at different melt temperatures using the data from Petitjean et al. (2010)

\begin{tabular}{|c|c|}
\hline Temperature (K) & $\begin{array}{c}\text { Glycolaldehyde Reaction } \\
\text { Cell Mixing Ratio (ppb) }\end{array}$ \\
\hline 298 & 1.8 \\
\hline 318 & 8.4 \\
\hline 338 & 39 \\
\hline 358 & 180 \\
\hline
\end{tabular}



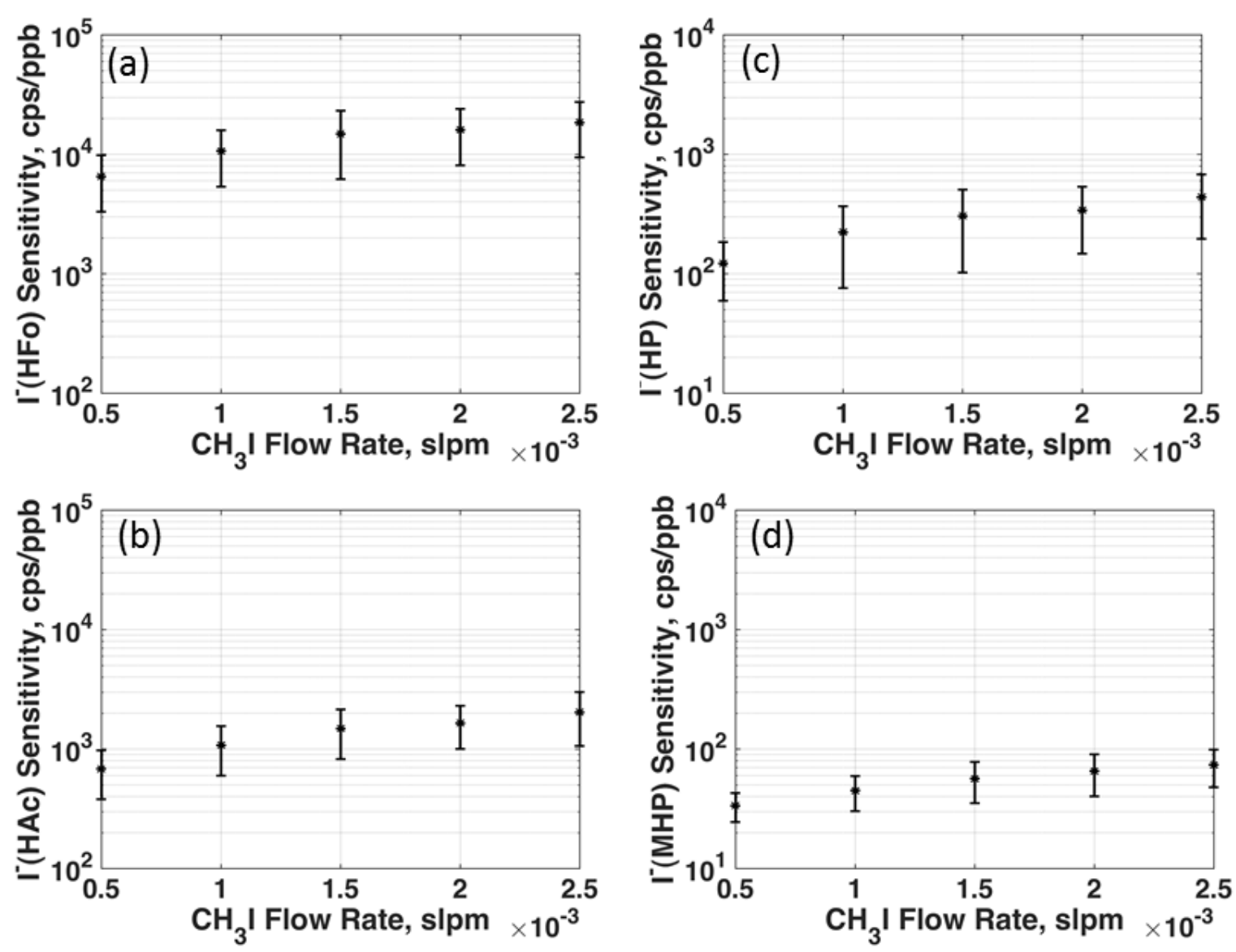

Figure S1: Laboratory calibration sensitivities (cps/ppb) as a function of $\mathrm{CH}_{3} \mathrm{I}$ flow rate (slpm) for a) $\mathrm{I}^{-}(\mathrm{HFo})$ at $\mathrm{m} / \mathrm{z} 173 \mathrm{~b}$ ) $\mathrm{I}^{-} \mathrm{HAc}$ at $\mathrm{m} / \mathrm{z}$ 187, c) $\mathrm{I}^{-}(\mathrm{HP})$ at $\mathrm{m} / \mathrm{z} 161$, and $\mathrm{d}^{-} \mathrm{I}^{-}(\mathrm{MHP})$ at $\mathrm{m} / \mathrm{z}$ 175. The error bars represent one standard deviation and the 80 variability represents variations in pressure, reaction cell water vapor, calibration gas precision, and instrumental precision. Note the change in the $\mathrm{y}$-axis scale for $\mathrm{c}$ and $\mathrm{d}$. 


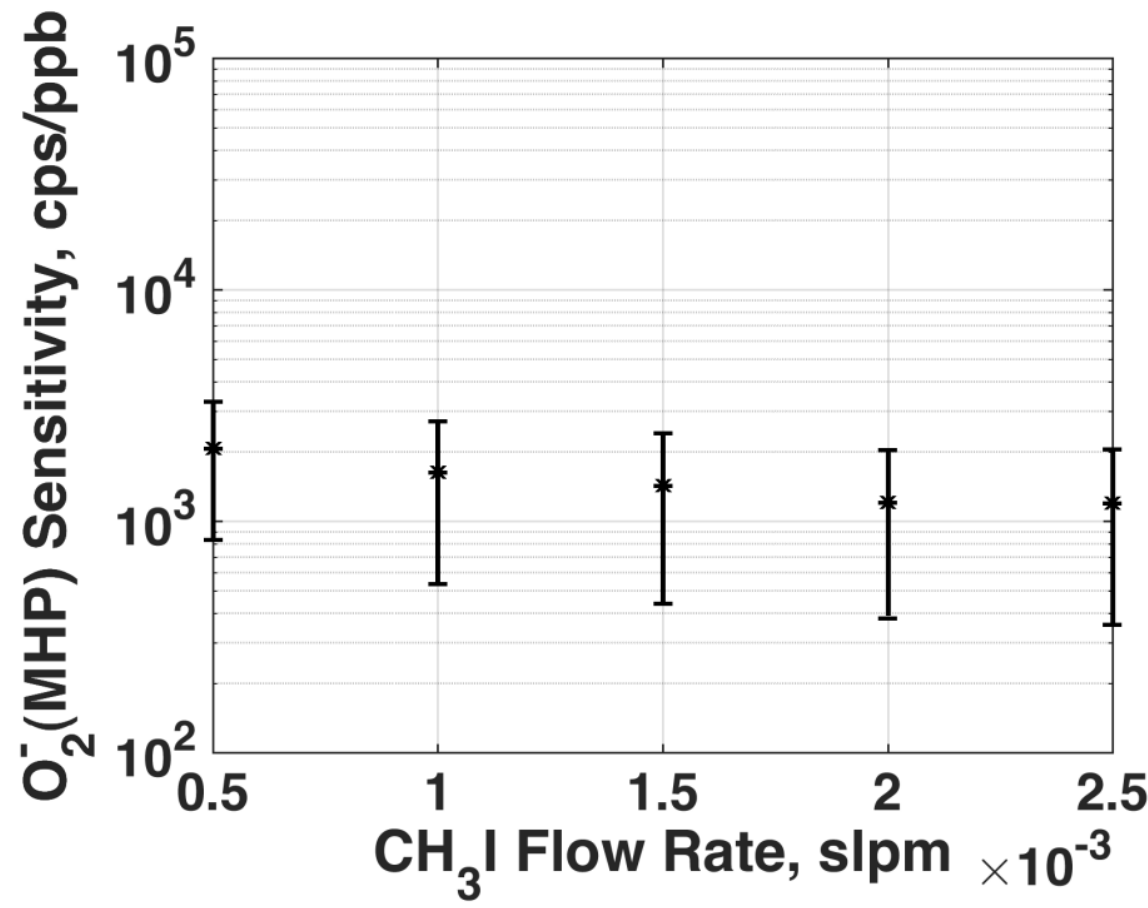

Figure S2: Laboratory calibration sensitivity (cps/ppb) as a function of $\mathrm{CH}_{3} \mathrm{I}$ flow rate (slpm) for $\mathrm{O}_{2}{ }^{-}(\mathrm{MHP})$ at $\mathrm{m} / \mathrm{z} 80$. The error bars are the same as in Fig. S1.

95 


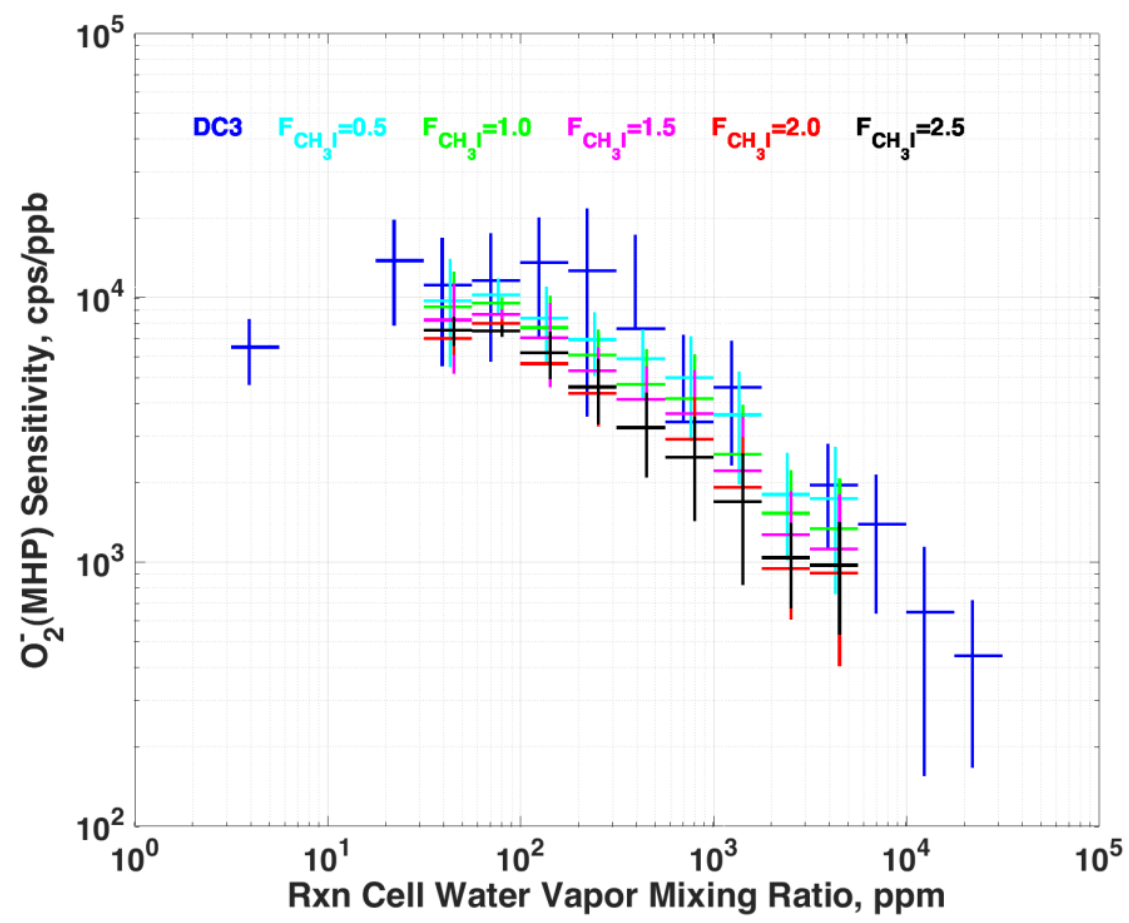

Figure S3: Calibration sensitivities (cps/ppb of $\mathrm{O}_{2}^{-}(\mathrm{MHP})$ at $\mathrm{m} / \mathrm{z} 80$ from $\mathrm{DC} 3$ and laboratory work for five $\mathrm{CH}_{3} \mathrm{I}$ flow rates $(0.5$ $2.0 \mathrm{sccm})$. The horizontal bar represents the limits of the reaction cell water vapor mixing ratio bin and the mean sensitivity of that bin is plotted. The length of the vertical bar represents one standard deviation and the variability represents random

110 variations in pressure, ambient concentrations during the standard addition, and systematic variations due to water vapor in a bin, calibration gas precision, and instrumental precision. 
Akagi, S. K., R. J. Yokelson, Ian R. Burling, Simone Meinardi, Isobel J. Simpson, D. R. Blake, G.R. McMeeking, et al. 2013"Measurements of Reactive Trace Gases and Variable O3 Formation Rates in Some South Carolina Biomass Burning Plumes.” Atmospheric Chemistry and Physics 13: 1141-65. doi:10.5194/acp-13-1141-2013.

Betterton, E. A. and Hoffmann, M. R.: Henry's law constants of some environmentally important aldehydes, Environ. Sci. Technol., 22(1), 1415-1418, doi:10.1021/es00177a004, 1988.

Johnson, T. J., Sams, R. L., Profeta, L. T. M., Akagi, S. K., Burling, I. R., Yokelson, R. J. and Williams, S. D.: Quantitative IR spectrum and vibrational assignments for glycolaldehyde vapor: Glycolaldehyde measurements in biomass burning plumes, J. Phys. Chem. A, 117(20), 4096-4107, doi:10.1021/jp311945p, 2013.

Kawamura, K., Okuzawa, K., Aggarwal, S. G., Irie, H., Kanaya, Y. and Wang, Z.: Determination of gaseous and particulate carbonyls (glycolaldehyde, hydroxyacetone, glyoxal, methylglyoxal, nonanal and decanal) in the atmosphere at Mt. Tai, Atmos. Chem. Phys., 13(10), 5227-5241, doi:10.5194/acp-13-5369-2013, 2013.

Kua, J., Galloway, M. M., Millage, K. D., Avila, J. E. and De Haan, D. O.: Glycolaldehyde monomer and oligomer equilibria in aqueous solution: Comparing computational chemistry and NMR data, J. Phys. Chem. A, 117(14), 29973008, doi:10.1021/jp312202j, 2013.

140 Lee, Y.-N., Zhou, X. and Hallock, K.: Atmospheric carbonyl compounds at a rural southeastern United States site, J. Geophys. Res., 100(D12), 25933, doi:10.1029/95JD02605, 1995.

Lee, Y.-N., Zhou, X., Kleinman, L. I., Nunnermacker, L. J., Springston, S. R., Daum, P. H., Newman, L., Keigley, W. G., Holdren, M. W., Spicer, C. W., Young, V., Fu, B., Parrish, D. D., Holloway, J., Williams, J., Roberts, J. M., Ryerson, T. B. and Fehsenfeld, F. C.: Atmospheric chemistry and distribution of formaldehyde and several multioxygenated carbonyl compounds during the 1995 Nashville/Middle Tennessee Ozone Study, J. Geophys. Res., 103(D17), 22449, doi:10.1029/98JD01251, 1998.

St. Clair, J. M., Spencer, K. M., Beaver, M. R., Crounse, J. D., Paulot, F. and Wennberg, P. O.: Quantification of hydroxyacetone and glycolaldehyde using chemical ionization mass spectrometry, Atmos. Chem. Phys., 14(8), 42514262, doi:10.5194/acp-14-4251-2014, 2014.

150 Okuzawa, K., Mochida, M., Bendle, J., Wang, H., and Kawamura, K.: Diurnal variation of semi-volatile dicarbonyls and hydroxycarbonyls in the urban atmosphere, Chikyukagaku (Geochemistry), 41, 125-134, 2007.

Petitjean, M., Reyès-Pérez, E., Pérez, D., Mirabel, P. and Le Calvé, S.: Vapor pressure measurements of hydroxyacetaldehyde and hydroxyacetone in the temperature range (273 to 356) K, J. Chem. Eng. Data, 55(2), 852855, doi:10.1021/je9004905, 2010.

155 Spaulding, R., Schade, G., Goldstein, A., Charles, M.: Characterization of secondary atmospheric photooxidation products: Evidence for biogenic and anthropogenic sources, J. Geophys. Res., 108(D8), 4247, doi:10.1029/2002JD002478, 2003. 